\title{
Innovation capability of managers in Nigerian large-scale manufacturing companies
}

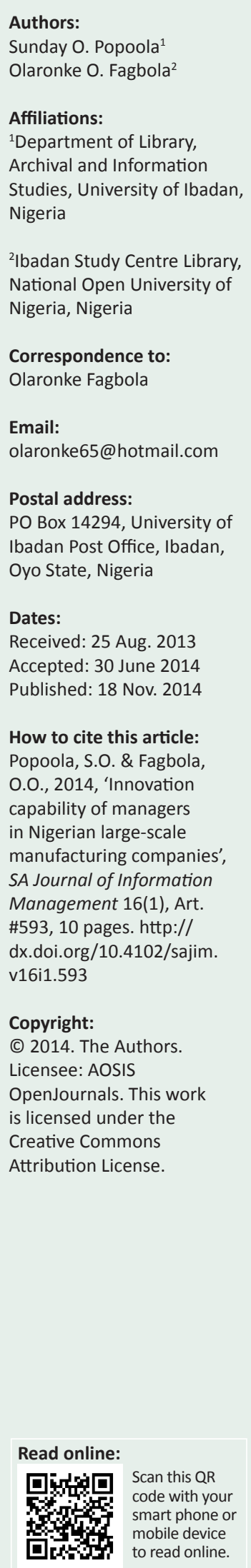

Background: Manufacturing companies in Nigeria operate in a turbulent business environment and managers therein need quality information to operate with keen market competition. Information seeking behavior and use as well as knowledge sharing are critical ingredients to enhance innovation capability of managers in business organisations like manufacturing companies for survival.

Objectives: This study examines the contributions of information-seeking behaviour, information utilation and knowledge sharing to the prediction of the innovation capability of managers in large-scale manufacturing companies in Nigeria with special reference to the food, beverages and tobacco companies.

Method: A total enumeration technique was used to administer copies of a questionnaire to a population of 400 managers in 12 food, beverages and tobacco companies that are listed on the Nigerian Stock Exchange. Of these, 357 responded. The response rate achieved was 89.3\%.

Results: The study found that there were significant multiple relationships between information-seeking behaviour, information utilisation, knowledge sharing and the innovation capability of the respondents. It was also found that information-seeking behaviour, information utilisation and knowledge sharing jointly and individually predict the innovation capability of the respondents. In addition, information-seeking behaviour contributed $22.18 \%$, information utilisation contributed $44.12 \%$, and knowledge sharing contributed $40.88 \%$ to the prediction of innovation capability of managers in food, beverages and tobacco companies in Nigeria. The study equally found that, apart from the traditional ways of sharing knowledge in organisations, social media technology such as Facebook and Twitter, amongst others, are new ways of sharing knowledge in large-scale manufacturing companies in Nigeria.

Conclusion: The study recommends that managers in these companies should be encouraged to seek for more information, make more intensive use of information and share knowledge in order to improve their innovation capability.

\section{Introduction}

Creativity and innovation is at the heart of modern businesses like manufacturing companies in Nigeria. Programmes of organisational innovation are typically tightly linked to organisational goals and objectives, to the business plan and to competitive positioning in the market. Davila, Epstein and Shelton (2006) noted that companies cannot grow through cost reduction and reengineering alone without innovation. Innovation is the key element in providing aggressive topline growth and in increasing bottom-line results. It is about introducing change into a relatively stable system (Marshall 2013). Many businesses embrace innovation with the primary goal of driving growth and consequently, improving shareholders' value, and making maximum profit. In general, manufacturing companies tend to spend a significant amount of their profits on innovation programmes, that is, making radical changes to their established products, processes and services.

Innovation is a new idea applied to initiating or improving a product, process or service. The concept of innovation encompasses new production-process technologies, new structures or administrative systems and new plans or programmes pertaining to organisational members. It is concerned with the work required to make an idea viable (Marshall 2013; Tidd 2001). In the organisational context, innovation may be linked to performance and growth through improvements in efficiency, effectiveness, productivity, quality of service and product, competitive positioning, market share and so on. Hesselbein, Goldsmith and Sommerville (2002) defined innovation as change that creates a new dimension of performance. Innovation is the new process, method, business model, partnership and route to a market (Sloane 2012). For the purpose of this study, innovation capability is defined as the successful exploitation of new 
ideals by the managers in any organisation, particularly manufacturing companies, to bring about radical or incremental changes to products, services and processes.

Information and knowledge are the basic ingredients needed by managers in organisations to bring about innovation. Information is data that has been processed into a form that is meaningful to the recipient or user and is of perceived value in current or future decisions. Information can also be seen as any communication or representation of knowledge such as facts, data, ideas, messages, opinions or images in any medium or form, including textual, numerical, graphic, cartographic, narrative or audio-visual forms. Information is a meaningful message transmitted from source to receivers or users. Information is an asset like the human resources, financial resources, material, machines and energy necessary for the efficient and effective management of business operations in order to produce high-quality products and services.

What is more, managers in businesses like manufacturing companies need and seek all forms of information such as legal, technical, commercial, political, economic, social, geographical, demographic and cultural information in order to improve their creative and innovative capabilities. Information-seeking success occurs in an organisation when a manager or an employee obtains the right information in the right format at the right place at the right time to the right extent at the right level and to the right amount with the least effort.

Krikelas (1983) stated that information-seeking begins when someone perceives that the current state of knowledge is less than that needed to deal with some issue or problem and that the process ends when the perception no longer exists. The need for creativity and innovation may put much pressure on the managers in businesses like manufacturing companies to seek and use information and knowledge. Baldwin and Rice (1997) reiterated that knowledge workers, including managers, continually search for new information. They monitor, store and disseminate company and industryrelated information. Their information-seeking behaviour may be influenced by their environment.

However, Zamani and Pezeshki (2005) averred that information behaviour is a broad term encompassing the ways in which individuals articulate their information needs and in which they seek, evaluate, select and use information. Information-seeking behaviour may be defined as all methods and ways by which an individual employed to search for, gain access to and retrieve needed information from various sources for use. Houtari and Wilson (2001) reported that the executive managers in both academic and business institutions in United Kingdom and Finland most often used meetings and personal contact to obtain internal and external information at the level of the company, but they used telecommunications (phone and fax) to get hold of external information at the level of marketing and sales. For the purpose of this study, the utilisation of information is defined as the correct application of messages, facts, opinions, signs, symbols, images, sounds, ideas, signals and processed data by the managers in order to bring about desired results from problems at hand, leading to innovation in an organisation.
Human knowledge is a critical factor in the production of goods and services in any organisation. Knowledge is obtained when an individual or manager uses information to resolve problems at hand or is better informed concerning a random event or phenomenon of which he or she has a gap in knowledge or understanding. Knowledge exists in people's minds. In the 'resource-based' view of the firm, knowledge is considered to be the most important strategic resource (Conner \& Prahaad 1996). Many organisations have recognised that knowledge is a valuable intangible resource that holds the key to competitive advantage (Kang, Chen \& Fang 2010).

Organisational creativity and innovation may be improved when managers and employees share knowledge. Knowledge sharing means that individuals mutually adjust their beliefs and actions through more or less intense interactions (Krough 2002). Knowledge sharing occurs in an organisation when the human elements therein are willing to share or transfer or distribute insights, experiences, preferences, lessons learned and effective practices amongst themselves. Business performance may be enhanced when knowledge is created, transferred and used for the common good of all categories of employees. Knowledge sharing may also be seen as the active process or act of communicating one's personal intellectual capital willingly to others and others freely receiving it. It is designed to transform individual knowledge into organisational knowledge (Adamovic, Potgieter \& Mearns 2012). The process of knowledge sharing in businesses is cyclical in nature, and modern organisation culture is synonymous with knowledge sharing processes (Adamovic et al. 2012).

In the last few years, manufacturing companies survived economically in spite of poor economic policies by the government in Nigeria. Their survival could be seen in terms of continued existence, quality products produced, increased sales and profits and improved production processes. In addition, their strong capital base, coupled with better corporate governance through the use of creativity and innovation programmes, could have made it possible for them to be listed on the Nigerian stock exchange (Popoola 2012).

In the minds of the researchers, the pertinent question which requires further investigation is: What is the innovation capability of organisations in Nigeria with regard to the information-seeking behaviour, information utilisation and knowledge sharing of their managers. Besides this, literature concerning the link between information-seeking behaviour and its utilisation for organisational innovation is scarce. It is in the light of this that the present study investigates the relationship between innovation capability and the information-seeking behaviour, information utilisation and knowledge sharing amongst managers in large-scale manufacturing companies in Nigeria with special reference to food, beverages and tobacco companies. 


\section{Purpose of the study}

The main purpose of this study is to examine the contribution of information-seeking, information utilisation and knowledge sharing to the prediction of innovation capability of managers in large-scale manufacturing companies in Nigeria.

\section{Research hypotheses}

The following hypotheses were formulated and tested at $\alpha=$ 0.05 level of significance to guide the study:

1. There is no significant multiple relationship amongst the information-seeking behaviour, information utilisation, knowledge sharing and innovation capability of the respondents.

2. Information-seeking behaviour, information utilisation and knowledge sharing will not significantly predict innovation capability of the respondents.

\section{Literature review}

Information is a construct with different meanings and interpretations, and as such, each author defines it from their own perspective. Information may be viewed as data that have been processed, organised and presented in a form which is comprehended to have significance and meaning to the recipient. Information can also be defined as ideas, opinions, messages, facts, images, sounds, codes, symbols, signs, signals, voices, computer programmes (software), databases, processed data or the like, obtained from published and unpublished sources. This information is capable of improving the knowledge state of a user concerning a random event or phenomenon. Therefore, information becomes knowledge when a user of information bridges the gap that exists in his or her understanding of a particular event or subject (Popoola 2006).

Houtari and Wilson (2001) defined human information behaviour as the totality of behaviour (active or passive) in which people engage to gain access to, organise and use information. Thus, it will comprise not only pro-active steps to gain access but also the passive reception of information, which then, or later, turns out to be of use (Wilson 1999). Information-seeking behaviour which results from the recognition of some need (Wilson 1997) is defined by Krikelas (1983) as any activity of an individual that is undertaken to identify a message that satisfies a perceived need. Chew (1994) suggests that, when an individual is driven to seek information as a result of 'needing to know', three modes of questioning behaviour are exhibited: questions to discover what is happening (orientation), questions to check that the person is on the right track (re-orientation) and questions to form an opinion or solve a problem (construction). Information-seeking behaviour may be defined as the purposive searching for information as a consequence of a need to satisfy some goal (Wilson 2000). For the purpose of this study, information-seeking behaviour may be viewed as all manners and ways by which managers in large-scale manufacturing companies identify, access and retrieve their needed information from the available sources in order to improve their innovation capability.

However, previous studies revealed that the personality (Heinstrom 2003), discipline (Ocholla 1999), task performance (Bystrom 2000), work performance (Popoola 2002), users' psychological characteristics (Wilson 2000) and individual characteristics (Allen \& Kim 2001) influenced the informationseeking behaviour of users. Before the relevant information is obtained, the searchers must overcome possible obstacles, which are sometimes psychological in nature. They must experience the situation as rewarding enough, and they themselves must be competent enough to actually take the final decision to seek for their needed information (Wilson 1981; Wilson \& Walsh 1996). Emotional aspects like feelings of frustration, impatience, information overload, resistance to new information and computer aversion may form barriers to the process to look for information (Nahl 2001). The feeling of uncertainty, often expressed as anxiety or worry, is strongly exhibited at the beginning of a search process when the users become aware of their lack of knowledge about the topic (Kuhlthau 1993). It must be noted that the cognitive ability of a manager in a business like a manufacturing company may influence his or her capacity to seek for needed information and use it for improved innovation capability. Motivation and interest influence the way in which information is used and critically evaluated (Limberg 1998). The more a manager is interested in and motivated to improve organisational creativity and innovation, the more likely it is that he or she will seek for more information.

Nevertheless, within the context of this study, the utilisation of information may be defined as the correct or suitable application of news, facts, messages, ideas, opinions, codes, symbols, signals, signs, images, sounds, voices, computer programmes (software), databases and processed data obtained from published and unpublished sources. The information is capable of improving the innovation capability of managers in manufacturing companies. Managers in businesses obtain their needed information from a wide range of formal sources such as libraries, record offices, online databases, Internet, textbooks, journals and trade literature as well as from informal sources like colleagues or subordinate staff. Blandin and Brown (1977) examined the relationship between perceived environmental uncertainty and the information search behaviour of top-level managers in four electronics firms and four wood-product firms in America. They found significant positive correlations between the level of perceived uncertainty and their reliance on external information sources, their use of informal information sources, their frequency of use of all information sources and the amount of time allocated to environmentally related information gathering.

Kotter (1982) reported that successful general managers in nine corporations in various industries in cities across the United States seek information aggressively, often by asking critical questions that provide useful answers for setting agendas. They rely more on information from discussions 
with individuals than on books, magazines or reports. Jones and McLeod (1986) explored the use of information sources by senior managers in the four decisional roles and reported that information from subordinates was frequently obtained and valued highly. White (1986) studied managers' information needs and use in manufacturing organisations in Britain and found that no correlation exist between the managers' functional roles (production, sales, marketing, finance or personnel) and their information needs. Further, marketing and sales managers, who are typically considered to be externally oriented, were found to use large amounts of internally produced data. Indeed, managers in manufacturing companies may demand and use information for equipment maintenance, financial planning, product development and marketing.

Popoola (2003) established that managers in oil companies in Nigeria sourced their needed information mostly from colleagues, subordinate staff, customers, government publications, newspapers and magazines, radio or television and internal reports. Information about competitors is merely one piece of all the relevant information that managers in organisations need when acquiring information from their business environment. They equally need, acquire and use information relating to the success of competitors' products in the market and the whole environment, including economic, legal, cultural and demographic background (Hermel 2001; Revelli 2000). Miller (2001) averred that business information could better be acquired from direct contact with customers, printed information documents and electronic information services. The specific information which executive managers and directors need and use to formulate business strategic plans and improve productivity in business organisations may include financial data, stock-market information, monetary and fiscal policies by government, mergers and acquisition of firms, technological information, business ownership and shareholders and advertising costs as well as information on financial crime. Benczur (2005) found that the acquisition and use of information in Western European companies to monitor their business environment so as to determine the course of action improved their sales volume. In actual fact, information and knowledge are very important resources that industrial firms need in order to foster creativity and innovation in their workforce. Input to an organisation come in the form of information resources and knowledge. Innovative organisations are active in reconfiguring new information resources and securing new knowledge. Information resources must be effectively managed, and knowledge must be shared to a great extent before organisations could enhance the creativity and innovation base of their workers. Luecke and Katz (2003) reiterated that innovation is generally understood as the introduction of a new thing or method, but innovation actually is the embodiment, combination or synthesis of knowledge in original, relevant and valued new products, processes or services.

Kim and Mauborgne (1999) claimed that organisations that have sustained high growth and profits follow a strategy of value innovation. A strategy of value innovation will allow an organisation to break out of a competitive imitative trap and make competitors irrelevant. Adamovic et al. (2012) remarked that organisations that share knowledge will gain improved innovation capability and hence sustain competitive advantage. O'Sullivan (2002) identified poor knowledge management, poor communication and a lack of access to relevant information, amongst others, as common causes of failure within the innovation process in most organisations. Knowledge is often defined as internalised information (Ingwersen 1992) and understood as a blend of explicit and tacit information (Nonaka 1994). This means that there are several kinds of knowledge at different levels of the organisation.

Knowledge lies in human minds and exists only if there is a human mind to do the knowing (Widen-Wulff \& Suomi 2007). Liebowitz (1999) believed that knowledge management is the process of knowledge identification, acquisition, saving, sharing, application and selling. According to Kathiravelu, Mansor and Kenny (2013), knowledge management can be described as the processes taken by firms to produce, maintain and share knowledge. Ajiferuke (2003) remarked that knowledge management involves the management of explicit knowledge, that is, knowledge that has been codified in documents, databases, webpages, et cetera and the provision of an enabling environment for the development, nurturing, utilisation and sharing of employees' tacit knowledge, that is, know-how, skills or expertise. The execution of an appropriate knowledge management programme in a business has the potential of improving customer services, continually improving business processes, quickly bringing new products to markets and bringing innovative new ideas to commercialisation (Heisig \& Vorbeck 2001).

Knowledge sharing is an important component of knowledge management. It is the procedure undertaken by people whenever an idea is to be exchanged. This can take the form of discussion, document exchange or faceto-face interaction so that new knowledge can be formed (Kathiravelu et al. 2013). With the advent of new technology, knowledge sharing has taken on new dimensions, hence the submission of Adamovic et al. (2012) that social media technology which are digital in nature (Facebook, Twitter, Wiki, blog) can assist the process of sharing knowledge in organisations because they allow easy and instant communication. The efficient and effective sharing and use of information and knowledge in organisations may foster creativity and innovation in employees. Knowledge sharing means that individuals mutually adjust their beliefs and actions through more or less intense interactions (Krough 2002). Knowledge sharing is the willingness of employees within an organisation to voluntarily donate their tacit knowledge or know-how, skills or expertise to others whilst others are happily collecting and applying the knowledge to solve creative and innovative problems. Liao, Fei and Chen (2007) reported that knowledge sharing and absorptive capacity has a significant correlation with the innovation 
capability amongst employees in Taiwan's knowledgeintensive industries. The systematic sharing of knowledge is assuming a larger role in all kinds of organisations around the world (Luen \& Al-Hawamdeh 2001; World Bank 1998). Morrow (2001) averred that the potential benefits of knowledge management abound and range from improving productivity, decision-making, customer service and innovation in an organisation. Be that as it may, the knowledge sharing which is an integral part of knowledge management has a tendency of bringing about improved work performance, creativity and innovation amongst employees in an organisation. Strategies for knowledge sharing in organisations include face-to-face interaction, discussion and document exchange. Lately knowledge sharing in organisations is also done via corporate intranets such as wikis, blogs, Facebook and Twitter. Social media technology provides the conduit and means for people to share knowledge, insights and experience (Bradley \& McDonald 2011).

However, innovation capability may be viewed as the ability of employees, particularly managers, to successfully exploit new ideas in order to bring about radical changes or improvements in methods, services and products in an organisation. Innovation is a critical activity for businesses that want to achieve competitive advantage and make super profits in dynamic markets. Organisational and strategic leadership research posits that strategic leaders or top managers heavily influence the organisation's capabilities by establishing an organisational culture, motivating and enabling managers and employees and building capacity for change and innovation (Daft 2001; Yukl 1999). The adoption of innovation involves the initiation of novel ideas that can successfully be executed to solve organisational problems. Novel ideas and solutions require knowledge and expertise (Mumford 2000). Education might provide individuals with specific knowledge needed for task performance and novel problem solving (Lee, Wong \& Chong 2005). Since the newness of innovation creates a sense of uncertainty, the managers' greater ability to gain information to reduce that uncertainty would facilitate the adoption of innovation (Rogers 1995). Arguably, information dissemination, information utilisation and knowledge sharing as well as level of education may influence the innovation capability of managers in an organisation.

\section{Research methodology}

An ex-post-facto descriptive research design was adopted for the study. This is because the independent variables (information-seeking behaviour, information utilisation and knowledge sharing) were not under the direct control of the researchers, and their manifestations having already occurred or because they are inherently not easy to manipulate. The relationship amongst the independent variables and dependent variable (innovation capability) was examined. The study population comprised of 400 managers in 12 food, beverage and tobacco companies quoted on the Nigeria Stock Exchange as at April 2008. The total enumeration technique was used to cover all 400 managers in the manufacturing companies studied. A set of tools was used for data collection, namely questionnaire-tagged information-seeking behaviour, information utilisation and the knowledge sharing and innovation capability of managers (ISBIUKSICM).

The questionnaire was divided into five main sections. Section-A deals with the demographic information of the respondents, for example gender, age, marital status, job tenure, job status, department of work and highest educational qualification. Section B contains 20 items that deals with the information-seeking behaviour of the respondents. The typical examples of the items are as follows:

- Most often, I seek the needed information from work mates and professional colleagues.

- When I experience an information overload in my workplace, I adopt the filtering method to obtain relevant information.

- I regularly browse through the Internet using known search engines to seek and obtain information.

The items were measured on a 4-point Likert Scale, namely very true of $m e=4$, true of me $=3$, occasionally true of me $=$ 2 and not true of me $=1$. It has a reliability coefficient of $\alpha=$ 0.83, using the Cronbach-Alpha method.

Section-C deals with the information utilisation of the respondents, that is, their utilisation of information sources and specific types of information utilised by the respondents. It was measured on a 4-point Likert Scale using the following response format: very highly utilised $=4$, highly utilised $=3$, occasionally utilised $=2$, not utilised $=1$. It has a reliability coefficient of $\alpha=0.74$, using the Cronbach-Alpha method, which is a method for determining the content validity of a measuring instrument used for data collection. Section D deals with knowledge sharing by the respondents. It has 10 items developed by Liao et al. (2007). The typical examples of the items are as follows:

- I often share with my colleagues the new working skills that I learn.

- Sharing knowledge with my colleagues is regarded as something normal in my company.

- Our company staff often exchanges knowledge of working skills and information.

The items were measured on a 5-point Likert Scale: totally agree $=5$, agree $=4$, neutral $=3$, disagree $=2$, totally disagree $=1$. It has a reliability coefficient of $\alpha=0.87$, using the Cronbach-Alpha method.

Section-E deals with innovation and management and consists of 18 items as developed by Liao et al. (2007). The typical examples of the items are as follows:

- Our company often develops new products and services well accepted by the market.

- The new manufacturing process or operation procedure employed by our company arouses imitation from competitors. 
- Our company emphasizes innovative and creative capability when recruiting staff.

The items were measured on a 5-point Likert Scale: totally agree $=5$, agree $=4$, neutral $=3$, disagree $=2$, totally disagree $=1$. It has reliability coefficients for product innovation $(\alpha$ $=0.93)$, process innovation $(\alpha=0.90)$, and management innovation $(\alpha=0.92)$. The overall reliability coefficient for the innovation capability scale is $\alpha=0.93$, using CronbachAlpha method.

The printed copies of the questionnaire were administered to 400 managers in the studied companies through physical contact with the help of five research assistants who were postgraduate students in the Department of Library, Archival and Information Studies, University of Ibadan, Ibadan, Nigeria. The census method was used to cover all 400 managers in large-scale manufacturing companies in Nigeria. Of the 400 managers, 357 responded, giving a response rate of $89.3 \%$. The questionnaire administration and response rate are shown in Table 1. The data that were collected were analysed using simple-correlation and multiple-regression analysis with the aid of Statistical Package for Social Sciences (SPSS). A simplecorrelation analysis was performed using Pearson's productmoment correlation method on the data collected from the field, namely information-seeking behaviour, information utilisation, knowledge sharing and innovation capability of the respondents. The independent variables are informationseeking behaviour, information utilisation and knowledge sharing whilst the dependent variable is innovation capability. Data on innovation capability were run on the independent variables using a multiple-regression analysis whilst Pearson's product-moment correlation method was used to correlate data on each of the independent variables on innovation capability of the respondents.

\section{Findings}

The gender distribution of the respondents showed that 255 (71.4\%) were males whilst 102 (28.6\%) were females.

This means that more males were recruited into the managerial positions in the food, beverage and tobacco companies in Nigeria. The age distribution of the respondents ranged between 23 and 49 years with mean age $=32.8(\mathrm{SD}=4.8)$ years. Of the 357 respondents, 158 (44.3\%) were single whilst the remaining 199 (55.7\%) were married. The distribution of the respondents' highest educational qualification revealed that $185(51.8 \%)$ had a bachelor degree, $97(27.2 \%)$ had a post-graduate diploma, and $75(21.0 \%)$ had master's degree in business-oriented disciplines. The job tenure of the respondents ranged between 8 and 32 years with the mean $=19.8(\mathrm{SD}=6.4)$ years.

The result of the study (Table 2) revealed that the very highly utilised information sources by the respondents were customers $=3.99(\mathrm{SD}=0.125)$, colleagues $=3.98(\mathrm{SD}=$ $0.128)$, trade literature $=3.96(\mathrm{SD}=0.126)$, Internet or online databases $=3.95(\mathrm{SD}=0.124)$, newspapers or magazines = $3.94(\mathrm{SD}=0.121)$, company files $=3.93(\mathrm{SD}=0.129)$, textbooks or journals $=3.92(\mathrm{SD}=0.123)$ and government publications $=3.90(\mathrm{SD}=0.127)$. The company library was never used = $1.44(\mathrm{SD}=0.028)$.

From Table 3, the mean and standard deviation scores of the major types of information utilised by the respondents were prices of goods and services $=4.99(\mathrm{SD}=0.128)$, labour matters $=4.97(\mathrm{SD}=0.212)$, tax laws $=4.97(\mathrm{SD}=$ 0.216), investment opportunities $=4.96(\mathrm{SD}=0.214)$, energy availability and costs $=4.96(\mathrm{SD}=0.213)$, financial data $=$ $4.94(\mathrm{SD}=0.212)$, technological $=4.93(\mathrm{SD}=0.218)$ and crime rate $=4.91(\mathrm{SD}=0.210)$.

It is shown in Table 4 that the major modes of knowledge sharing by the respondents in large-scale manufacturing companies in Nigeria are staff meetings $(100.0 \%)$, personal contact $(100.0 \%)$, the telephone $(99.4 \%)$, email $(98.6 \%)$, work progress reports $(98.0 \%)$, social media (Facebook, Twitter, Wikis, etc., $67.2 \%)$, blogs (56.0\%), et cetera. However, instant messaging (29.4\%) and newsgroups (5.6\%) were amongst the least-used modes of knowledge sharing by managers in large-scale manufacturing companies in Nigeria.

Table 5 presents a summary of the test for a significant relationship between information-seeking behaviour, information utilisation, knowledge sharing and innovation capability of the respondents.

TABLE 1: Questionnaire administration and response rate.

\begin{tabular}{llll}
\hline Company & Population & Number responded & Response rate (\%) \\
\hline 7-up Bottling Company, PLC & 65 & 54 & 83.1 \\
Big Treat, PLC & 20 & 20 & 100.0 \\
Cadbury Nigeria, PLC & 45 & 40 & 88.9 \\
Dangote Flour Mills, PLC & 20 & 20 & 100.0 \\
Dangote Sugar Refinery, PLC & 22 & 18 & 81.0 \\
Ferdinand Oil Mill, PLC & 15 & 15 & 100.0 \\
Flour Mills Nigeria, PLC & 18 & 18 & 100.0 \\
National Salt Company Nigeria PLC & 22 & 20 & 90.9 \\
Nestle Nigeria, PLC & 25 & 22 & 88.0 \\
Nigeria Bottling Company, PLC & 75 & 65 & 86.7 \\
UTC Nigeria, PLC & 45 & 40 & 88.9 \\
Nigeria Flour Mills, PLC & 28 & 25 & 89.3 \\
\hline Total & $\mathbf{4 0 0}$ & $\mathbf{3 5 7}$ & $\mathbf{8 9 . 3}$ \\
\hline
\end{tabular}

PLC, Public limited company 
TABLE 2: Mean and standard deviation score of information utilisation (sources) of the respondents.

\begin{tabular}{lll}
\hline Information sources & $\overline{\boldsymbol{x}}$ & SD \\
\hline Customers & 3.99 & 0.125 \\
Colleagues & 3.98 & 0.128 \\
Trade literature & 3.96 & 0.126 \\
Internet/online databases & 3.95 & 0.124 \\
Newspapers/magazines & 3.94 & 0.121 \\
Company files & 3.93 & 0.129 \\
Textbooks/journals & 3.92 & 0.123 \\
Government publications & 3.90 & 0.127 \\
Company library & 1.44 & 0.028 \\
\hline
\end{tabular}

$\bar{x}$, mean; SD, standard deviation.

TABLE 3: Mean and standard deviation score of types of information utilised by the respondents.

\begin{tabular}{lll}
\hline Information types & $\overline{\mathbf{x}}$ & SD \\
\hline Prices of goods and services & 4.99 & 0.128 \\
Labour matters & 4.97 & 0.212 \\
Tax laws & 4.97 & 0.216 \\
Investment opportunities & 4.96 & 0.214 \\
Energy availability and costs & 4.96 & 0.213 \\
Financial data & 4.94 & 0.212 \\
Technological & 4.93 & 0.218 \\
Crime rate & 4.91 & 0.210 \\
\hline
\end{tabular}

$\bar{x}$, mean; SD, standard deviation.

TABLE 4: Distribution of respondents by modes of knowledge sharing in large-scale manufacturing companies in Nigeria ( $N=357)$.

\begin{tabular}{|c|c|c|c|c|}
\hline \multirow[t]{2}{*}{ Modes of knowledge sharing } & \multicolumn{2}{|c|}{ Yes } & \multicolumn{2}{|c|}{ No } \\
\hline & $n$ & $\%$ & $n$ & $\%$ \\
\hline Email & 352 & 98.6 & 5 & 1.40 \\
\hline Teleconferencing & 250 & 70.0 & 107 & 30.0 \\
\hline Instant messaging & 105 & 29.4 & 252 & 70.6 \\
\hline Telephone & 355 & 99.4 & 2 & 0.06 \\
\hline Work progress report & 350 & 98.0 & 7 & 2.0 \\
\hline Blogs & 200 & 56.0 & 157 & 44.0 \\
\hline Discussion groups & 100 & 28.0 & 257 & 72.0 \\
\hline News group & 20 & 5.60 & 337 & 94.9 \\
\hline Personal contact & 357 & 100.0 & - & - \\
\hline Social media (Facebook, blog, Twitter, Wiki's) & 240 & 67.2 & 117 & 32.8 \\
\hline
\end{tabular}

TABLE 5: Summary of test of significant relationship amongst information-seeking behaviour, information utilisation, knowledge sharing and innovation capability of the respondents.

\begin{tabular}{llll}
\hline Variables & $\overline{\boldsymbol{x}}$ & SD & Significant $\boldsymbol{P}$ \\
\hline Information-seeking behaviour (ISB) & 22.56 & 4.42 & 0.554 \\
Information utilisation (IU) & 24.68 & 4.68 & 0.036 \\
Knowledge sharing (KS) & 28.42 & 5.34 & 0.642 \\
Innovation capability (IC) & 30.24 & 5.43 & 0.586 \\
\hline
\end{tabular}

$\bar{x}$, mean; SD, standard deviation; IC, innovation capability; $r$, correlation coefficient.

The mean and standard deviation scores of informationseeking behaviour of the respondents are $=22.56$ (SD $=$ 4.42) whilst the mean and standard deviation scores of their innovation capability are $=30.24(\mathrm{SD}=5.43)$. Therefore, there is a significant relationship between information-seeking behaviour and innovation capability of the respondents $(r=$ $0.554 ; p<0.05)$. Also, the mean and standard deviation scores of information utilisation of the respondents are $=24.68$ $(\mathrm{SD}=4.68)$ whilst the mean and standard deviation scores of their innovation capability are $=30.2(\mathrm{SD}=5.43)$. Thus, there is a significant relationship between the information utilisation and innovation capability of the respondents $(r=0.642 ; p<0.05)$. The mean and standard deviation scores of the knowledge sharing of the respondents are $=28.42$ $(\mathrm{SD}=5.34)$ whilst the mean and standard deviation scores of their innovation capability are $=30.24$ ( $\mathrm{SD}=5.43)$. It is therefore established that there is a significant relationship between knowledge sharing and innovation capability of the respondents $(r=0.586 ; p<0.05)$.

Table 6 shows the summary of a multiple-regression analysis of information-seeking behaviour, information utilisation and knowledge sharing on innovation capability of the respondents. 
TABLE 6: Summary of multiple-regression analysis of information-seeking behaviour, information utilisation and knowledge sharing on innovation capability of the respondents.

\begin{tabular}{lllll}
\hline Source of Variation & $\boldsymbol{d f}$ & SS & MS & S-ratio \\
\hline Due to Regression & 3 & 1923.66 & 641.22 & - \\
Due to Error & 353 & 10108.42 & 28.64 & - \\
\hline Total & 356 & $\mathbf{1 2 0 3 2 . 0 8}$ & $\mathbf{6 6 9 . 8 6}$ & $\mathbf{2 2 . 3 9}$ \\
\hline
\end{tabular}

Note: Adjusted $R^{2}=0.3914$; Adjusted $R=0.6256$; Standard Error of Estimate (SEE) = $5.35 d f$, degrees of freedom; SS, sum of squares; MS, mean square.

TABLE 7: Summary of test of significance of independent variables to the prediction of innovation capability of the respondents.

\begin{tabular}{llllll}
\hline Variables & $d f$ & REq. Coeff (B) & SE (B) & Betain & Significant $\boldsymbol{P}$ \\
\hline Constant & 353 & 0.1806 & 0.1246 & - & 0.082 \\
Information-seeking behaviour (ISB) & 353 & 0.2141 & 0.0448 & 0.2218 & 4.45 \\
Information utilisation (IU) & 353 & 0.4222 & 0.0681 & 0.4412 & $0.036^{*}$ \\
Knowledge sharing (KS) & 353 & 0.3316 & 0.0652 & 0.4088 & 5.09 \\
\hline
\end{tabular}

$*$, significant at $\alpha=0.05$

$d f$, degrees of freedom; REq. Coeff(B), coefficient of regression model; $\mathrm{SE}(\mathrm{B})$, standard error of Betain; Betain, relative contribution value; $T$, student's t-statistic.

The test of hypothesis one revealed that there is a significant multiple relationship amongst informationseeking behaviour, information utilisation, knowledge sharing and innovation capability of the respondents $(R=$ 0.6256; $p<0.05)$.

More so, the test of hypothesis two shows that informationseeking behaviour, information utilisation and knowledge sharing, when taken together, significantly predict the innovation capability of the respondents $(F(3 ; 353)=22.39$; $p<0.05)$. Further, a post-hoc test reveals that each of the independent variables, that is, information-seeking behaviour $(B=0.2141 ; d f=353 ; T=4.78 ; p<0.05)$, information utilisation $(B=0.4222 ; d f=353 ; T=6.20 ; p<0.05)$ and knowledge sharing $(B=0.3316 ; d f=353 ; T=5.09 ; p<0.05)$ significantly predict the innovation capability of the respondents. This could not have happened due to chance because going by the adjusted $R^{2}$ value of 0.3914 , one can argue that about $39.14 \%$ of the total variance in innovation capability of managers in the largescale manufacturing companies in Nigeria is explained by a linear combination of their information-seeking behaviour, information utilisation and knowledge sharing.

This can mathematically be expressed thus IC $=0.2141 \mathrm{ISB}$ $+0.4222 \mathrm{IU}+0.3316 \mathrm{KS}$. Furthermore, going by the values of Betain, one can therefore submit that information-seeking behaviour contributed 22.18\%, information utilisation contributed $44.12 \%$ and knowledge sharing contributed $40.88 \%$ to the prediction of innovation capability of the respondents.

\section{Discussion of findings}

Managers in business organisations function in the world of information. They also operate within an informationrich environment where different information sources are available to them to acquire their needed information for improving their creativity and innovation capability. This study found that customers, colleagues, reports, trade literature, Internet or online databases, newspapers or magazines, company files, textbooks or journals and government publications were very highly utilised information sources by the managers of food, beverages and tobacco companies in Nigeria.
Similarly, (Choo 1994; O'Connell \&Zimmerman 1979; Olatunji 1994; Stabell 1978) reported that managers in manufacturing companies most frequently utilised customers, colleagues, online information services, newspapers or magazines, broadcast media (radio and television), reports, company files, trade literature and government publications. It is very surprising to find that the respondents never made use of the information resources and services in their company library. Lester and Waters (1989) support this finding by reporting that managers in large United Kingdom companies considered traditional sources, such as libraries, as too tedious and frustrating to use. They are also sceptical about the value of information-brokering services.

This study further revealed that the major types of information utilised by the managers in food, beverage and tobacco companies in Nigeria were prices of goods and services, labour matters, tax laws, investment opportunities, energy availability and costs, financial data, technological information and crime rate. Adebisi (2006) remarked that most managers in Nigerian manufacturing companies made use of price data, tax laws, monetary policies, export and import data, exchange rates, labour matters and scientific and technical matters in producing value-added goods. The study of large South Korean firms by Goshal and Kim (1986) concluded that managers required and made use of information about the immediate business environment, that is competitors, existing technologies, product markets, general social, economic and political matters. Similarly, Revelli (2000) and Hermel (2001) remarked that managers in organisations need, acquire and use information relating to the success of competitors' products in the market and the whole environment, including the economic, legal, cultural and demographic background.

Nevertheless, this study also found that informationseeking behaviour, information utilisation and knowledge sharing had a significant multiple relationships with the innovation capability of the managers in food, beverages and tobacco companies in Nigeria. Bawden (1986) posited that information utilisation may affect the creativity and innovation of users. Access and the ability for contact 
and information exchange with external organisational systems as well as good information-seeking behaviour by the working force are essential for innovation in an organisation (Fennel 1984; Kimberly 1978). The process to adopt innovation in organisations has been divided into a variety of phases, namely awareness, initiation, selection, adoption, implementation and routinisation (Klein \& Sorra 1996). It must be noted that information-seeking behaviour, information utilisation and knowledge sharing are essential ingredients at every stage of the innovation process in an organisation. Liao et al. (2007) found that knowledge sharing has a positive influence on the innovation capability amongst employees of Taiwan's knowledge-intensive industries.

However, the most critical finding of this study is that information-seeking behaviour, information utilisation and knowledge sharing significantly predicts the innovation capability of managers in food, beverages and tobacco companies in Nigeria. This does not occur by a mere chance because about $39.14 \%$ of the total variance in innovation capability of managers in food and beverages and tobacco companies in Nigeria can be attributed to a linear combination of their information-seeking behaviour, information utilisation and knowledge sharing. In addition, informationseeking behaviour contributed $22.18 \%$, information utilisation contributed $44.12 \%$ and knowledge sharing contributed $40.88 \%$ to the prediction of the innovation capability of the respondents. Arguably, information utilisation can be regarded as the greatest contributor to the prediction of innovation capability of managers in food, beverages and tobacco companies in Nigeria.

\section{Conclusion and recommendation}

Innovation is the spinal cord of the modern competing organisational environment. Also in the fiercely and keen competitive 21st century market place, innovative ability is essential for company survival. Successful innovative firms therefore cultivate creative ideals that add value to their produced goods and services. Information and knowledge has been accepted widely as the corporate assets that businesses must exploit in order to improve their business performance. Information availability, accessibility and utilisation as well as knowledge creation, transfer, sharing and use are critical factors that are considered necessary for facilitating organisational creativity and innovation in the business world. How well the workforce, particularly the managers in organisations, has been able to meet their information and knowledge requirements will determine the extent of their creative and innovative capabilities. This study therefore established that information-seeking behaviour, information utilisation and knowledge sharing jointly and individually predict the innovation capability of the managers in food, beverages and tobacco companies in Nigeria and that information utilisation is the most potent contributor to the prediction of the innovation capability of the respondents. Based on the major findings of this study, it is therefore recommended that managers in the studied companies be encouraged to make more intensive use of information in order to improve their innovation capability. Management should provide a conducive environment for knowledge sharing amongst the managers to improve their innovation capability. They should be encouraged to seek for accurate, reliable and complete information so as to enhance their innovation capability. The management of the companies should provide education and training on creativity and innovation to their workforce, particularly managers. Library staff should also provide information literacy programmes in order to stimulate the level of demand and use of their information resources and services amongst the managers in the studied companies.

\section{Acknowledgements Competing interests}

The authors declare that they have no financial or personal relationship(s) that may have inappropriately influenced them in writing this article

\section{Authors' contributions}

S.O.P. (University of Ibadan) contributed by means of Conceptualising the study; background to the study; literature review; design and validity of the measuring instrument (Questionnaire); and the data analysis and interpretations. O.O.F. (National Open University of Nigeria) contributed to this article through the literature review; field administration/data collection; data editing; abstract.

\section{References}

Adamovic, D., Potgieter, A. \& Mearns, M., 2012, 'Knowledge sharing through social media: Investigating trends and technologies in a global marketing and advertising research', South African Journal of Information Management (14)1, Art. \#514, 7 pages. http://dx.doi.org/10.4102/sajim.v14i1.514

Adebisi, M.O., 2006, 'Role of information management and information use in business performance of manufacturing firms', Journal of Organizational Development 18(2), 140-151.

Ajiferuke, I., 2003, 'Role of information professionals in knowledge management programmes: Empirical evidence from Canada', Informing Science June, 329-339.

Allen, B.L. \& Kim, K.S., 2001, 'Person and context in information seeking: Interaction between cognitive and task variables', New Review of Information Behaviour Research 2, 1-16.

Baldwin, N.S. \& Rice, R.E., 1997, 'Information-seeking behaviour of securities analysts: Individual and institutional influences, information sources and channels, and outcomes', Journal of the American Society for Information Science 48(8), 674-693. http://dx.doi.org/10.1002/(SICI)1097-4571(199708)48:8\%3C674::AIDASI2\%3E3.0.CO;2-P

Bawden, D., 1986, 'Information systems and the stimulation of creativity', Journal of Information Science 12(4), 203-216. http://dx.doi.org/10.1177/ 016555158601200501

Benczur, D., 2005, 'Environmental scanning: How developed is information acquisition in Western European companies?', Information Research 11(1), 1-18.

Blandin, J.S. \& Brown, W.B., 1977, 'Uncertainty and management's search for information', Institute of Electrical and Electronics Engineers, Transaction on Engineering Management 24(4), 14-19.

Bradley, A.J. \& McDonald, M.P., 2011, Social media versus knowledge management, HBR Blog Network, viewed 20 July 2013, from http://blogs.hbr.org/2011/10/ social-media-versus-knowledge

Bystrom, K., 2000, 'The effects of task complexity on the relationship between information types acquired and information source used', New Review of Information Behaviour Research 1, 85-101.

Chew, F., 1994, 'The relationship of information needs to issue relevance and media use', Journalism Quarterly 71, 676-688. http://dx.doi. org/10.1177/107769909407100318

Choo, C.W., 1994, 'Perception and use of information sources by chief executives in environmental scanning', Library and Information Science Research (16)1, 23-40. $\mathrm{http}: / / \mathrm{dx}$.doi.org/10.1016/0740-8188(94)90040-X 
Conner, K.R. \& Prahaad, C.K., 1996, 'A resource based theory of the firm: Knowledge versus opportunism', Organization Science 7, 477-501. http://dx.doi.org/10.1287/ versus opportun
orsc.7.5.477

Daft, R.L., 2001, 'Organization theory and design, South-western, Cincinnati.

Davila, T., Epstein, M.J. \& Shelton, R., 2006, Making innovation work: How to manage it, measure it, and profit from it, Wharton School Publishing, Upper Saddle River.

Fennel, M.L., 1984, 'Synergy, influence and information in the adoption of administrative innovations', Academy of Management Journal 27(2), 113-129. http://dx.doi.org/10.2307/255960

Goshal, S. \& Kim, S.K., 1986, 'Building effective intelligence systems for competitive advantage', Sloan Management Review 28(1), 49-58.

Heinstrom, J., 2003, 'Five personality dimensions and their influence on information behaviour', Information Research 9(1), 1-23.

Heisig, P. \& Vorbeck, J., 2001, 'Bench marking survey results', in K. Martins, P. Heisig \& J. Vorbeck (eds.), Knowledge management: Best practices in Europe, pp. 97-123, Springer-Verlag, Berlin. http://dx.doi.org/10.1007/978-3-662-04466-7_6

Hermel, L., 2001, Maitriser et pratiquer la veille strateique, Afnor, Paris.

Hesselbein, F., Goldsmith, M. \& Sommerville, I., 2002, Leading for innovation: And organizing for results, Jossey-Bass, London.

Houtari, M. \& Wilson, T.D., 2001, 'Determining organizational information needs: The critical success factors approach', Information Research 6(3), 1-15.

Ingwersen, P., 1992, Information retrieval and interaction, Tyler, London.

Jones, J.W. \& McLeod, R., 1986, 'The structure of executive information systems: An exploratory analysis', Decision Sciences 17(2), 220-249. http://dx.doi. An exploratory analysis', Decision Scienc
org/10.1111/j.1540-5915.1986.tb00223.x

Kang, Y., Chen, G., Ko, C. \& Fang, C., 2010, 'The exploratory study of on-line knowledge sharing by applying wiki collaboration system', Scientific Research 2, 243-248. http://dx.doi.org/10.4236/ib.2010.23031

Kathiravelu, S.R., Mansor, N.N.A. \& Kenny, K., 2013, 'Factors influencing knowledge sharing behaviour (KSB) among employees of public services in Malaysia' International Journal of Academic Research in Economics and Management Sciences 2(3), 107-119.

Kim, W.C. \& Mauborgne, R., 1999, 'Strategy, value, innovation and the knowledge economy', Sloan Management Review Spring, 41-54.

Kimberly, J.R., 1978, 'Hospital innovation adoption: The role of integration into external information environments', Journal of Health and Social Behaviour 19(2) 361-373. http://dx.doi.org/10.2307/2136583

Klein, K.J. \& Sorra, J.S., 1996, 'The challenge of innovation implementation', Academy of Management Review 21, 1055-1080. http://dx.doi.org/10.2307/259164

Kotter, J.P., 1982, 'What effective general managers really do', Harvard Business Review 60(6), 156-167.

Krikelas, J., 1983, 'Information seeking behaviour: Patterns and concepts', Drexel Library Quarterly 19, 5-20.

Krough, G., 2002, 'The communal resource and information systems', Journal of Strategic Information Systems 11, 85-107. http://dx.doi.org/10.1016/S09638687(02)00006-9

Kuhlthau, C.C., 1993, Seeking meaning: A process approach to Library and Information Services, Ablex, Norwood.

Lee, S.H., Wong, P.K. \& Chong, C.L., 2005, 'Human and social capital explanations for R and D outcome', Institute of Electrical and Electronics Engineers Transactions on Engineering Management 52, 59-68. http://dx.doi.org/10.1109/ TEM.2004.839955

Lester, R. \& Waters, J., 1989, 'Environmental scanning and business strategy, London: British Library, Research and Developmental Department', Library and Information Research Report 75, 1-148.

Liao, S., Fei, W. \& Chen, C., 2007, 'Knowledge sharing, absorptive capacity, and innovation capability: An empirical study of Taiwan's knowledge-intensive industries', Journal of Information Science 33(3), 340-359. http://dx.doi. org/10.1177/0165551506070739

Liebowitz, J., 1999, 'Key ingredients to the success of an organization's knowledge management strategy', Knowledge and Process Management 6(1), 37-40. http:// dx.doi.org/10.1002/(SICI)1099-1441(199903)6:1\%3C37::AID-KPM40\%3E3.

Limberg, L., 1998, Att Soka information for all lara, Gothenburg, Valfrid.

Luecke, R. \& Katz, R., 2003, Managing creativity and innovation, Harvard Business School Press, Boston.

Luen, T.W. \& Al-Hawamdeh, S., 2001, 'Knowledge management in the public sector: Principles and practice in police work', Journal of Information Science 27, 311318. http://dx.doi.org/10.1177/016555150102700502

Marshall, D., 2013, 'There's a critical difference between creativity and innovation', viewed 15 July 2013, from http://www.businessinsider.com/difference-betweencreativity-and-innovation-2013-4
Miller, M.A., 2001, 'Influence of business information sources' utilization on workers' productivity', Journal of Corporate Banking Management 10(2), 58-64.

Morrow, N.M., 2001, 'Knowledge management: An introduction', Annual Review of Information Science and Technology 35, 381-422.

Mumford, M.D., 2000, 'Managing creative people: Strategies and tactics for innovation', Human Resources Management Review 10(2), 313-355. http:// dx.doi.org/10.1016/S1053-4822(99)00043-1

Nahl, D., 2001, 'A conceptual framework for explaining information behaviour', Studies in Media and Information Literacy Education 1(2), 1-12. http://dx.doi. org/10.3138/sim.1.2.001

Nonaka, I., 1994, 'A dynamic theory of organizational knowledge creation', Organizational Science 5(1), 44-55. http://dx.doi.org/10.1287/orsc.5.1.14

Ocholla, D., 1999, 'Insights into information-seeking and communicating behaviour of academics', International Information and Library Review 31(3), 111-143. http:// dx.doi.org/10.1006/iilr.2000.0116

O'Connell, J.J. \& Zimmerman, J.W., 1979, 'Scanning the international environment', California Management Review 22(2), 15-23. http://dx.doi. org/10.2307/41165317

Olatunji, O.A., 1994, 'Availability and utilization of information sources and services in Cadbury Nigeria PLC, Lagos', MLS dissertation, Department of Library, Archival and Cadbury Nigeria PLC, Lagos', MLS dissertation, Depa
Information Studies, University of Ibadan, Ibadan.

O'Sullivan, D., 2002, 'Framework for managing development in the networked organizations', Journal of Computers in Industry 47(1), 77-78. http://dx.doi. org/10.1016/S0166-3615(01)00135-X

Popoola, S.O., 2002, 'Information-seeking behaviour and use as correlates of perceived work performance of corporate Insurance managers in Nigeria', Ife Behavioural Research 4(1), 14-34.

Popoola, S.O., 2003, 'Environmental scanning for strategic advantage of managers in oil companies in Nigeria', Nigeria Libraries 37(1), 42-56.

Popoola, S.O., 2006, 'Information accessibility and utilization as factors influencing decision-making of managers in commercial banks in Nigeria', Library Herald 44(2), 89-110.

Popoola, S.O., 2012, 'Information utilization capacity and organizational development in Nigeria', paper presented at a Training workshop on Information for Industrial Development, organized by Economic Management Group at Eko Hotel, Lagos, Nigeria, 10-12 October.

Revelli, C., 2000, Intelligence strategique sur Internet, Dunod, Paris.

Rogers, E.M., 1995, Diffusion of innovation, Free Press, New York.

Sloane, P., 2012, 'What's the difference between creativity and innovation?', viewed 25 July2013, from http://www.innovationexcellence.com/blog/2012/08/04/ whats-the-difference-between-creativity-and -innovation/

Stabell, C., 1978, 'Integrative complexity of information environment perception and information use: An empirical investigation', Organizational Behaviour and Human Performance 22 (1), 116-142. http://dx.doi.org/10.1016/0030-5073(78)90009-0

Tidd, J., 2001, 'Innovation management in context: Environment, organization and performance', International Journal of Management Review 3(3), 169-183. http://dx.doi.org/10.1111/1468-2370.00062

White, D.A. 1986, 'Information use and needs in manufacturing organizations: Organizational factors in information behaviour', International Journal of Information Management 6(3), 157-170. http://dx.doi.org/10.1016/0268 4012(86)90003-4

Widen-Wulff, G. \& Suomi, R., 2007, 'Utilization of information resources for business success: The knowledge sharing model', Information Resources Management Journal 20(1), 46-67. http://dx.doi.org/10.4018/irmj.2007010104

Wilson, T.D., 1981, 'On user studies and information needs', Journal of Documentation 37(1), 3-15. http://dx.doi.org/10.1108/eb026702

Wilson, T.D., 1997, 'Information behaviour: An inter-disciplinary perspective', Information Processing and Management 33(4), 551-572. http://dx.doi. org/10.1016/S0306-4573(97)00028-9

Wilson, T.D., 1999, 'Models in information behaviour research', Journal of Documentation 55(4), 249-270. http://dx.doi.org/10.1108/EUM0000000007145

Wilson, T.D., 2000, 'Human information behaviour', Information Sciences 3(2), 49-55.

Wilson, T.D. \& Walsh, C., 1996, Information behaviour: An inter-disciplinary perspective, British Library Research and Information Centre, London.

World Bank, 1998, 'Knowledge for development', World Development report, no. 21, viewed 10 March 1999, from http://www.worldbank.org/wdr/wdr98/index.htm

Yukl, G., 1999, 'An evaluative essay on current conceptions of effective leadership', European Journal of Work and Organizational Psychology 8(2), 33-48. http:// dx.doi.org/10.1080/135943299398429

Zamani, N. \& Pezeshki-Rad, G., 2005, 'Information-seeking behaviour of Iranian extension managers and specialists', Information Research 10(3), 1-10. 